УДК: 378.141.+ 81.28+811.114

Боднар Світлана Вікторівна

кандидат педагогічних наук, доцент кафедри іноземних мов

Одеський інститут фінансів Українського державного університету

фінансів і міжнародної торгівлі, м. Одеса, Україна

bodnar@sana.od.ua

\title{
ВИКОРИСТАННЯ ІНТЕРНЕТ-ТЕХНОЛОГІЙ У СИСТЕМІ АВТОНОМНОГО ВИВЧЕННЯ ПРОФЕСІЙНО-ОРІЄНТОВАНОЇ ІНОЗЕМНОЇ МОВИ СТУДЕНТАМИ НЕМОВНИХ СПЕЦАЛЬНОСТЕЙ
}

\begin{abstract}
Анотація. У статті проаналізовано проблеми використання Інтернет-технологій у системі автономного вивчення професійно-орієнтованої іноземної мови студентами немовних спеціальностей. Висвітлюються різні підходи у сучасній педагогічній літературі щодо визначення поняття “автономне навчання” як специфічного виду навчально-пізнавальної діяльності. Розглядаються можливості використання засобів інформаційно-комунікаційних технологій під час автономного навчання студентів немовних спеціальностей іноземної мови. Зазначаються переваги використання Всесвітньої мережі Інтернет під час навчання іноземних мов, виокремлюються засоби навчання і види самостійної роботи з іноземної мови 3 використанням інформаційних технологій. Наводяться приклади певних завдань 3 використанням Інтернет-технологій.
\end{abstract}

Ключові слова: Інтернет-технології; автономне навчання; іноземні мови.

\section{1. ВСТУП}

Інтеграція України в міжнародний економічний та інформаційний простір зумовлює потребу пошуку нових підходів до навчання майбутніх спеціалістів іноземних мов відповідно до міжнародних стандартів мовної компетенції. Особливої значущості набуває формування у фахівців навичок і вмінь професійного ділового спілкування іноземною мовою.

Постановка проблеми. Зростання інформаційного потоку в умовах значного розширення ділових, професійних і культурних зв’ язків України з країнами СС вимагає від випускника немовного закладу рівня володіння іноземною мовою не нижче В2 (незалежного користувача), який відповідає сучасним європейським стандартам [3]. Це зумовлює необхідність розробки нових підходів до навчання іноземної мови як обов'язкової дисципліни у немовному вищому навчальному закладі (ВН3), упровадження в навчальний процес інноваційних технологій навчання і методик, що сприятимуть формуванню навичок і вмінь професійно-орієнтованого спілкування на базі набутої системи знань.

Аналіз досліджень і публікацій. Проблеми використання Інтернет-технологій у навчанні іноземних мов досліджувалися такими вченими, як: Е.Г. Азімов, П. Г. Асоянц, Т. І. Коваль, Н. І. Муліна, Е. Л. Носенко, П. І. Сердюков, О. Б. Тарнапольський, Г. С. Чекаль, Н. М. Чемерис, Т. Аптон, П. Бракамонте, К. Х. Брючер, М. П. Коллинс, П. Данкель, К. Ричардвордс, М. Симонсон, А. Томпсон та ін. Попри це питання застосування Інтернет-технологій на заняттях з іноземної мови у немовному ВНЗ як передумови організації навчальної автономії студентів залишається ще недостатньо розробленим.

Тому об'єктом нашого дослідження $є$ автономне навчання іноземної мови. Предмет - Інтернет-технології у системі автономного навчання студентів немовних спеціальностей іноземної мови. Мета статті полягає в організації навчальної автономії 
студентів у вивченні професійно-орієнтованої іноземної мови засобом Інтернеттехнологій.

\section{2. МЕТОДИ ДОСЛІДЖЕННЯ}

3 метою характеристики сучасного стану викладання ділової англійської мови в немовних вищих навчальних закладах і визначення змісту професійно орієнтованого навчання студентів економічного напряму використано метод аналізу й узагальнення даних з літературних джерел. Для вивчення й узагальнення ефективності практичного досвіду навчання майбутніх фахівців економічних спеціальностей ділового англійського мовлення використано метод анкетування. 3 метою розробки моделі організації навчального процесу на основі навчальної автономії студентів із використанням Інтернет-технологій, обгрунтування відповідної системи вправ застосовано методи синтезу (угрупування, класифікація).

\section{3. РЕЗУЛЬТАТИ ДОСЛІДЖЕННЯ}

Навчальна автономія розуміється як наявність «здатності тих, хто навчається, брати на себе відповідальність за результати навчання» [8] щодо всіх аспектів своєї навчальної діяльності, а саме: встановлення цілей, визначення змісту й послідовності, добір матеріалів, управління процесом і оцінювання отриманих результатів. Можна додати до цього визначення ще таке, яке витікає з узагальненого визначення будь-якої автономії як «здатність суб' єкта самостійно здійснювати свою навчальну діяльність, активно й свідомо керувати нею, забезпечувати її рефлексію й корекцію, накопичувати індивідуальний досвід, відповідально та незалежно приймати кваліфіковані рішення щодо навчання у різних навчальних контекстах при певному ступені незалежності від викладача» $[2,12]$. Щодо вивчення іноземної мови, навчальна автономія визначається як внутрішня особиста незалежність студента, що базується на його здатності самостійно керувати процесом засвоєння знань й оволодінням навичками й уміннями іншомовного спілкування [5]

На думку О. Б. Тарнопольського [5], під розвитком навчальної автономії розуміється не стільки впровадження суто індивідуального (незалежного - independent learning) навчання, скільки комплекс заходів, використання яких веде до того, що студенти самі (індивідуально і як група в цілому) значною мірою беруть на себе відповідальність за хід і результати навчального процесу. Одним з ефективних заходів організації навчальної автономії студентів виступають Інтернет-технології, які сприяють оптимізації навчального процесу у немовних вишах.

Доцільно зазначити, що завдяки Інтернету виникла віртуальна реальність, яка стає новим технологічним, психофізіологічним і соціокультурним способом буття людини, формує принципово новий характер її спілкування, специфічними особливостями якого стають віртуальність, інтерактивність, гіпертекстуальність. Для викладачів комп'ютерне (віртуальне) середовище слугує підгрунтям для розробки сучасних засобів навчання. Викладач отримує можливість постійного оновлення навчального матеріалу завдяки використанню в процесі навчання сучасних автентичних електронних документів та інших Інтернет-ресурсів. Він може адаптувати й доповнювати вже закладені у базу даних програми матеріали, не тільки узгоджуючи їх із віковими особливостями і професійними інтересами студентів, але й інтегруючи зміст програм у соціокультурне середовище студентів. Також викладач за допомогою IКT надає студентам, 3 одного боку, більше автономії (фізичної, соціальної, лінгвістичної та 
когнітивної), а з іншого - "соціалізує" процес навчання, дозволяючи зробити його результат доробком багатьох зацікавлених осіб (через роздрук матеріалів, роботу в мережі Інтернет), а також створювати колективні творчі роботи студентів не тільки однієї групи, а навіть навчальних закладів, розташованих у різних містах і країнах.

Так, у багатьох вищих навчальних закладах активно практикуються представлення й динамічне оновлення освітніх ресурсів викладачів фахових навчальних дисциплін, зокрема їхніх web-сторінок i web-сайтів 3 демонстраційними матеріалами, текстами лекцій, добірками наукових статей, анотованими посиланнями на Інтернет-ресурси тощо.

Для студентів комп'ютерне середовище виступає засобом створення продуктів власного учіння. Готовність студентів до вивчення іноземної мови в комп'ютерному середовищі передбачає засвоєння комунікативних і операційних умінь, підготовку до розумової діяльності: уміння усвідомити задачу - сприйняти іiї ціль як особистісно значущу, проаналізувати умови, спланувати структуру дій i організувати пошук відсутньої інформації, підібрати раціональний алгоритм эї вирішення. Важливим $\epsilon$ не тільки вміння отримати результат, а й оцінити його повноту, достовірність, проаналізувати доцільність і ефективність своїх дій.

Безсумнівно, використання Всесвітньої мережі Інтернет у навчальному процесі має цілу низку переваг: варіативність застосування матеріалів на різних етапах навчання; можливість їх застосування на будь-якому етапі роботи на практичному занятті; краще сприймання i запам'ятовування навчального матеріалу; економне використання навчального часу; індивідуалізація навчання, визначення глибини i послідовності засвоєння, темпу роботи; скорочення видів роботи, що викликають утомлюваність студентів; використання різних аудіовізуальних засобів навчання (графіки, звуку) для збагачення і мотивації навчання, наочного і динамічного подання матеріалу; розгалуження послідовності навчання на основі аналізу помилок; створення комфортного середовища для сучасного навчання; активізація навчальної діяльності студентів; інтенсифікація навчання й підвищення рівня мотивації; формування самооцінки студента і створення умов для його самостійної роботи.

Попри це, необхідно зауважити, що одержувана з Інтернету інформація завжди актуальна, аутентична за змістом, формою і функцією, підготована професіоналами, високої якості, кольорова, 3 фотографіями, графіками та діаграмами (або навіть мультимедійна), відповідає індивідуальним інтересам і потребам, "розвантажує" підручник від великих інформаційних текстів на користь актуальних мотивуючих текстів і на користь вправ. Також перевагою Інтернету є мультимедійний гіпертекст 3 великою кількістю зв'язків і посилань на інші джерела інформації. Порівнюючи друкований текст і гіпертекст, треба зазначити, що студентам цікавіше працювати в Інтернеті, оскільки всі Web-матеріали є реальними, сучасними й актуальними, що і $\epsilon$ причиною підвищення мотивації під час виконання різноманітних завдань.

Застосування Інтернет-технологій в автономному навчанні іноземної мови $\epsilon$ цілком виправданим, тому що більшою мірою спонукає студента до самонавчання i передбачає такі види діяльності, які можна застосовувати без безпосереднього втручання викладача: для пошуку мовної інформації у мережі - використання webбраузерів, баз даних; користування інформаційно-пошуковими й інформаційнодовідковими системами, автоматизованими бібліотечними системами, електронними журналами; для організації діалогу в мережі - використання електронної пошти, електронних дошок об'яв (Bulletin Board System), Chat, Forum, Blogs або Skypeтехнологій; для створення тематичних web-сторінок i web-квестів - використання htmlредакторів, web-браузерів, графічних редакторів; для представлення результатів наукових досліджень - публікації в електронних журналах, участь у комп'ютерних 
конференціях (телеконференції Usenet News i ехо-конференції), міжкультурних проектах.

Завдяки включенню до навчального процесу електронної пошти, телеконференцій i чатів зростає роль іншомовного читання і листування. Означені служби Інтернету пропонують справжній міжкультурний діалог у новій формі, яка не є типовою ані для навчальних, ані для реальних ситуацій, ані для традиційного листування. Під час навчання іншомовного читання і листування форма перестає домінувати над змістом, здійснюється синхронна й асинхронна письмова комунікація, а також існує можливість використати її результати для розвитку інших видів комунікативної діяльності. Наразі також виникає можливість ввести у пам'ять i/або роздрукувати свої і чужі тексти (тобто відстрочені аналіз, самоперевірка і самоконтроль), що призводить до значного покращення грамотності.

Використовуючи інформаційні ресурси мережі Інтернет, можна самостійно розв'язувати і задачі лінгвокраїнознавчого характеру, такі як, наприклад, знайомитися 3 культурознавчими відомостями, що включають у себе мовленнєвий етикет, особливості мовного поводження носіїв мови, особливості культури, традицій країни мови, яка вивчається. Наприклад, студенти мають можливість знайти інформацію на англомовних сайтах про вибори Президента країни (Президента США), події в різних куточках світу, про художні й публіцистичні твори певних сучасних англомовних авторів, особливість утворення в Англії національної кухні, традиції святкування певних свят, наприклад Різдва, Великодня, і представити цю інформацію в аудиторії для обговорення. Можна наразі підібрати цікаві ілюстрації, а також звернути увагу інших студентів на найсучаснішу мову, якою подається ця інформація, і порівняти іiі з тими застиглими варіантами, 3 якими найчастіше мають справу студенти, коли їх практика обмежується тільки друкованою художньою літературою. У цьому ми бачимо віртуальний діалог двох культур, стимульований реальними контактами 3 представниками цієї культури.

До можливих видів самостійної роботи 3 іноземної мови 3 використанням інформаційних технологій ми рекомендуємо віднести такі.

1. Мовні тренінги 3 лексики і граматики. Використання тренінгів допомагає розвивати навички писемного мовлення, перекладу, розширювати словниковий запас, підготуватися до міжнародних іспитів. Тренінги економлять час викладача, тому що не потрібно перевіряти механічно ступінь володіння лексикою (він має результати, сформовані комп'ютером), викладач продовжує розвивати навички використання лексики у комунікативному процесі.

2. Тести вхідного, проміжного та вихідного контролів знань студентів. Результати тестування вносяться в електронні протоколи, студенти i викладачі можуть ознайомитися з ними в будь-який час.

3. Проблемно-пошукові завдання на базі Інтернет-ресурсів. Для реалізації таких завдань студенти і викладачі використовують інформаційні і комунікаційні служби Інтернету, пошукові системи, каталоги та колекції посилань. Викладач формулює для студентів певну проблему чи коло проблемних завдань і пропонує механізм для успішної реалізації цієї задачі. Залежно від типу завдання технології розв'язання проблеми можуть бути різними (з урахуванням рівня володіння іноземною мовою i навичками використання Інтернету і комп'ютера).

4. Творчі завдання (створення міні-презентацій за темами за вибором). Студентам пропонуються теми, за якими впродовж начального семестру вони готують презентації. Викладач надає тільки консультативну допомогу щодо змісту, джерел інформації, оформлення та захисту роботи. Результатом є комп'ютерні презентації, виконані у Microsoft Power Point, з використанням текстової, графічної, аудіо- та відеоінформації. 
Наведемо приклади завдань, що базуються на роботі з інформаційними ресурсами мережі Інтернет під час організації автономного навчання.

Завдання 1. Використовуючи матеріали культурологічного веб-сайту http://www.camelotintl.com/tower_site/index.html, здійсніть віртуальну екскурсію (Virtual Tour) 3 гідом по Лондонському Тауеру. Включіть звук і прослухайте інформацію екскурсовода про історію, традиції, королівські скарби, привидів, ув'язнених історичних фігур, легенди та байки англійською мовою. Використовуйте інтерактивну мапу-схему.

Завдання 2. Ознайомитись із системою освіти Нової Зеландії. За допомогою матеріалів веб-сайту www.teachnz.govt.nz/environment/edusystem.html дізнайтеся, який вигляд має типовий день студента Нової Зеландії. Підготуйте порівняльну таблицю типового дня студента з Нової Зеландії, Великобританії, США та України.

Завдання 3. За допомогою мережі Інтернет зберіть інформацію за певною темою (Наприклад, "Employment agencies and their work"), користуючись ключовими словами через так звані „механізми пошуку” (search engines). Підготуйте нотатки для обговорення проблеми працевлаштування в Україні і країнах Європи.

Завдання 4. Зайдіть на веб-сайт британської газети "Guardian Unlimited" (http://www.guardian.co.uk/), оберіть статтю за темою, що вивчається, й обговоріть ії на форумі газети. Результати обговорення представте у вигляді тез.

Завдання 5. Зробіть перевірку вашого правопису. Вийдіть на сайт http://grammar.ccc.commnet.edu/grammar/quiz_list.htm, оберіть розділ "Spelling”, виконайте запропоновані тести. Зробіть аналіз помилок. Виконайте завдання ще раз. Проаналізуйте результати (чи є зміни порівняно з попереднім виконанням тесту).

Завдання 6. Робота 3 інтерактивним відео. Зазначена програма - це фільм англійською мовою. У процесі перегляду цього фільму глядач реагує на ситуації, запропоновані комп'ютером (відповідає на запитання героїв фільму, керує їхніми діями), і так сам стає учасником розвитку подій. Використання такого варіанту „карооке” суттєво актуалізує знання студентів, надає можливості формування їхніх умінь в аудіюванні й говорінні.

Завдання 7. Виконання завдання за допомогою мережі Інтернет за темою “А јob interview” («Співбесіда при прийомі на роботу»). Студентам надаються посилання на адреси сайтів, що містять приклади проведення співбесіди під час прийому на роботу он-лайн:

- http://eleaston.com/biz/home.html;

- http://www.businessenglishonline.net/TheBusiness/powerpointpresentations.htm;

- http://www.businessenglishpod.com/2010/04/18/bep-158-int-dealing-with-an-angrycaller.

Завдання передбачало самостійно переглянути цей матеріал, ознайомитися зі зразками написання резюме англійською мовою, скласти своє резюме, послати його на сайт працевлаштування, відповісти на додаткові запитання, якщо вони з'являлися, i зарекомендувати себе так, щоб вам запропонували роботу (у нашому випадку будь-яку роботу). До аудиторії принести підтвердження, що вам запропонували цю роботу.

Під час автономного навчання студентів рекомендується також активно використовувати Інтернет-проекти в навчальному процесі. На нашу думку, проектна робота сприяє формуванню не тільки іншомовної комунікативної компетенції студентів, а й інформаційної компетенції. Метод проектів припускає використання широкого спектру проблемних, дослідницьких, пошукових методів, орієнтованих на чіткий і реальний практичний результат, який має значення для кожного студента, що брав участь у розробці проекту, а також розробку проблеми цілісно з урахуванням різних чинників і умов її розв'язання і реалізації результатів. 
Наводимо приклад проекту, який можна рекомендувати для використання на заняттях 3 англійської мови у немовних вишах. "Підготуйте проект за наступним завданням. Ви - представник одного з Університетів Великобританії. Ви виступаєте перед майбутніми студентами. Ви маєте переконати їх, що ваш Університет - один із найкращих і найпопулярніших у країні, і вони обов'язково мають вчитися тільки у ньому. Для того, щоб Ваша промова була переконливою, використайте рекламні буклети, фотографії, слайд-шоу.”

Матеріали: друковані матеріали, (http://www.britannica.com, http://www.encarta.com, http://www.islandsinfo.com/, $\quad$ http://www.fount.com/, електронні матеріали http://www.globalearn.org, http://www.yahoo.com/University/, http://www.teacher_hall.com/druk/uk.doc).

Строк виконання: 1 місяць. Форма роботи: індивідуальна. Форма оформлення результатів: презентація у формі слайд-шоу (для підготовки презентації Ви можете обрати одну з програм Microsoft PowerPoint, Corel Presentation, Lotus Freelance Graphics, StarOffice Impress). Форма презентації: аудиторна.

Означений проект відноситься до інформаційно-творчих мовних проектів середньої тривалості. Крім чіткої тимчасової протяжності для проекту характерна сувора структурованість. Він сприяє розвитку комунікативних і дослідницьких умінь майбутніх фахівців і формуванню у них умінь і навичок роботи з інформацією.

Ще одним із видів роботи, які рекомендуються для автономного навчання іноземної мови, є робота 3 автентичними фаховими лекціями викладачів вищих навчальних закладів Англії/Америки за такими загальними темами, що вивчаються майже в усіх, наприклад, економічних вузах, на певному курсі. Це стає можливим завдяки використанню сучасних Інтернет-технологій, що пов'язують університети різних країн і дають можливість україномовним студентам прослуховувати лекції разом $з$ англомовними студентами, які знаходяться поряд $з$ лектором по той бік екрану, в on-line режимі. Крім того, наші студенти мають можливість записати ці лекції на відеодиск і прослуховувати їх ще декілька разів для повного розуміння змісту. Після прослуховування наші студенти в аудиторії обговорюють, що вони зрозуміли 3 лекції іноземною мовою і що викликало найбільше ускладнення. У ході обговорення студенти доходять загальних висновків щодо результативності пред'явлення лекційного матеріалу і щодо того, чи зможуть вони вчитися в зарубіжному університеті i повноцінно сприймати фаховий матеріал. Для кращого розуміння іншомовного матеріалу, україномовним студентам рекомендується спочатку прослухати лекції рідною мовою за тією ж темою.

Зауважимо, що сучасні студенти також мають можливість брати участь в on-line конференціях, що нині перебуває на стадії активного впровадження у процес навчання і дає позитивні результати щодо підготовки фахівців до професійної діяльності. On-line конференції є електронною проекцією звичайних конференцій, оскільки спілкування відбувається також у реальному часі і йому характерні всі засоби усного мовлення. Єдиною відмінністю $є$ широта аудиторії, місце проведення і технічні обмеження. Алгоритм проведення on-line конференцій такий: визначається тема конференціï, iii ведучий і терміни проведення; оголошується збір доповідей і публікується прес-реліз конференції, який розсилається в інші ВНЗ; у зазначений час проводиться презентація і обговорення доповідей; конференція завершується. Публікуються результативні зведення. Серед різновидів інтернет-конференцій є скайп-конференції; friendfeedконференції/семінари; wiki-конференціï/семінари; інтегровані конференції, коли використовуються різні середовища і сервіси (wiki і блоги або Skype) [1].

Зазначимо, що для більшості студентів такі «живі» конференції виявилися мотиваційно-спрямованими, бо сприяли розвитку англомовних умінь спілкування в 
реальній, а не штучно створеній ситуації. Проведені on-line сеанси поєднують частково підготовлене і спонтанне мовлення і дозволяють наочно прослідкувати застосування відомих правил і прийомів аргументації у реальній комунікації.

Під час on-line сеансів в аудиторії доцільно проводити контроль результатів навчання. Викладач і його асистенти фіксують мовлення кожного студента на аудіодиск, потім аналізують створений дискурс і виставляють бали.

Також для оцінювання своїх результатів під час автономного навчання доцільно використовувати електронні портфелі. Електронні портфелі розробляються з метою проведення комп'ютеризованого оцінювання, у тому числі в режимі он-лайн [6, 119121]. Електронні портфелі $є$ подібними до традиційних, оскільки вони також складаються з робіт студента, але виконані в електронному форматі. Це можуть бути текстові документи, відео, аудіоматеріали, електронні щоденники або веб-сайти, які демонструють рівень досягнень того, хто навчається, не тільки у формальному навчальному середовищі, але й у позааудиторній роботі.

\section{4. ВИСНОВКИ ТА ПЕРСПЕКТИВИ ПОДАЛЬШИХ РОЗВІДОК}

3 усього вищесказаного можна дійти висновку, що для автономного навчання студентів іноземної мови вкрай необхідно застосовувати Інтернет-технології, які сприятимуть заохоченню студентів до самостійної роботи у своєму власному режимі і в той же час підвищуватиме мотивацію до вивчення іноземної мови. Отже, для здійснення результатоцентрованої англомовної підготовки майбутнього фахівця в умовах інформаційного суспільства слід спрямувати цілі, зміст, структуру і сам процес викладання дисциплін англомовного циклу на постійний розвиток i саморозвиток студента, стимулювати активність студента через поширення IКТ як інструменту творчої навчальної-пізнавальної і майбутньої професійної діяльності.

\section{СПИСОК ВИКОРИСТАНИХ ДЖЕРЕЛ}

1. Интернет-конференция : методические материалы [Электронный словарь]. - Режим доступа : http://wiki.iot.ru.

2. Коряковцева Н. Ф. Автономия учащегося в учебной деятельности по овладению иностранным языком как образовательная цель / Н. Ф. Коряковцева // Иностранные языки в школе. - 2001. № 1. - С. 9-14.

3. Програма з англійської мови для професійного спілкування / Г. С. Бакаєва, О. А. Борисенко, I. І. Зуєнок [та ін.]. - К. : Ленвіт, 2005. - 119 с.

4. Тамбовкина Т.Ю. К проблеме автономии обучающихся иностранному языку в педвузе / Т. Ю. Тамбовкина // Иностранные языки в школе. - 1998. - № 4. - С. 84-88.

5. Тарнопольський О. Б. Шляхи розвитку автономії студентів на курсах англійської мови для ділового спілкування / О. Б. Тарнопольський //Актуальні проблеми викладання іноземних мов у вищій школі : зб. наук. праць. - Донецьк : ДонНУ, 2002. - С. 130-135.

6. Dudeney G., Hockly N. How to teach English with technology / Series editor: Jeremy Harmer. - Harlow : Pearson Education Limited, 2007. - 192 p.

7. Holec H. Autonomy in Foreign Language Learning / H. Holec. - Oxford University Press, 1981. - 89 p. 


\title{
ИСПОЛЬЗОВАНИЕ ИНТЕРНЕТ-ТЕХНОЛОГИЙ В СИСТЕМЕ АВТОНОМНОГО ОБУЧЕНИЯ ПРОФЕССИОНАЛЬНО-ОРИЕНТИРОВАННОГО ИНОСТРАННОГО ЯЗЫКА СТУДЕНТАМИ НЕЯЗЫКОВЫХ СПЕЦИАЛЬНОСТЕЙ
}

\author{
Боднар Светлана Викторовна \\ кандидат педагогических наук, доцент кафедры иностранных языков \\ Одесский институт финансов Украинского государственного университета \\ финансов и международной торговли, г. Одесса, Украина \\ bodnar@sana.od.ua
}

\begin{abstract}
Аннотация. В статье освещаются проблемы использования Интернет-технологий в системе автономного изучения профессионально-ориентированного иностранного языка студентами неязыковых специальностей. Изучаются различные подходы в современной педагогической литературе по поводу определения понятия “автономное обучение” как специфического вида учебно-познавательной деятельности. Рассматриваются возможности использования информационно-коммуникационных технологий во время автономного обучения студентов неязыковых специальностей иностранному языку. Анализируются преимущества использования Всемирной сети Интернет при изучении иностранных языков, выделяются средства обучения и виды самостоятельной работы по изучению иностранных языков при помощи информационных технологий. Приводятся примеры заданий с использованием Интернет-технологий.
\end{abstract}

Ключевые слова: Интернет-технологии; автономное обучение; иностранные языки.

\section{INTERNET-TECHNOLOGY USAGE IN THE SYSTEM OF AUTONOMOUS BUSINESS ENGLISH LEARNING BY NON-LINGUISTIC STUDENTS}

\author{
Svitlana V. Bodnar \\ Ph.D. in Pedagogy, Associate Professor of Foreign Languages Department, \\ Odessa Institute of Finance of Ukrainian State University \\ of Finance and International Trade, Odessa, Ukraine \\ bodnar@sana.od.ua
}

\begin{abstract}
The article highlights the problems of Internet-technology usage in the system of autonomous Business English learning by non-linguistic students. Different approaches which exist in contemporary pedagogical science as to defining the notion "autonomous learning" as a specific kind of educational-cognitive activity are considered. Attention is focused on the possibilities of IT technology usage in the process of autonomous foreign language learning at non-linguistic Universities. The advantages of World Wide Web usage in the process of foreign language learning are specified. The means of teaching and the kinds of independent work on foreign language learning by means of IT technology are presented in the article. The samples of tasks based on IT technology application are suggested.
\end{abstract}

Keywords: Internet-technology; autonomy learning; foreign languages.

\section{REFERENCES (TRANSLATED AND TRANSLITERATED)}

1. Internet-conference : methodological materials [online] . - Available from: http://wiki.iot.ru. (in Russian)

2. Korjakovtseva N. F. Pupils' autonomy in teaching foreign languages as an educational goal // Foreign languages at school. - 2001. - № 1. - P. 9-14. (in Russian)

3. English for Specific Purposes. National Curriculum for Universities / G. Bakayeva, O. Borysenko, I. Zuyenok [and others]. - K. : Lenvit, 2005. - 119 p. (in Ukrainian) 
4. Tambovkiba T. U. To the problem of pupils' autonomy learning a foreign language in the pedagogical university / T. U. Tambovkina // Foreign languages at school. - 1998. - № 4. - P. 84-88. (in Russian)

5. Tarnopolsky O. B. The ways of students' autonomy development at the English courses for specific purposes / O. B. Tarnopolsky // Actual problems of teaching foreign languages at high educational establishments : collection of scientific works .-- Donetsk : DonNu, 2002. - P. 130-135. (in Ukrainian)

6. Dudeney G., Hockly N. How to teach English with technology / Series editor: Jeremy Harmer. - Harlow : Pearson Education Limited, 2007. - 192 p. (in English)

7. Holec H. Autonomy in Foreign Language Learning / H. Holec. - Oxford University Press, 1981. - 89 p. (in English) 